\title{
Expression of the Voltage-Gated Chloride Channel CIC-2 in Rod Bipolar Cells of the Rat Retina
}

\author{
Ralf Enz, ${ }^{2}$ Brenda J. Ross, ${ }^{1}$ and Garry R. Cutting ${ }^{1}$ \\ 1 Institute of Genetic Medicine and Department of Pediatrics, The Johns Hopkins University School of Medicine, \\ Baltimore, Maryland 21287, and 2Institut für Biochemie, Friedrich-Alexander-Universität Erlargen-Nürnberg, 91054 \\ Erlangen, Germany
}

\begin{abstract}
Voltage-gated chloride channels (CIC) are highly conserved during evolution and appear to participate in a variety of physiological functions. Recently, CIC-2 was proposed to play a role in stabilizing the chloride equilibrium potential near or below the resting membrane potential in neurons expressing ligand-gated chloride channels. Because rod bipolar cells in mammalian retina express three forms of inhibitory ligand-gated chloride channels, we decided to study $\mathrm{CIC}-2$ localization and function in the rat retina. RNA encoding $\mathrm{CIC}-1,-2,-3,-4$, and -5 was detected by reverse transcription-PCR in the rat retina. CIC-2specific antibodies identified protein on cell bodies and in synaptic layers. Double-immunofluorescence staining revealed that intense CIC-2 immunoreactivity colocalized with PKCstained rod bipolar cells. Patch-clamp experiments performed
\end{abstract}

with individual rod bipolar cells demonstrated the presence of a time-dependent, inwardly rectified current activated at hyperpolarizing membrane potentials. This current demonstrated selectivity for different anions $\left(\mathrm{Cl}^{-}>\mathrm{I}^{-}>\right.$gluconate), was inhibited by $\mathrm{Cd}^{2+}$, and was minimally reduced by $4,4^{\prime}-$ diisothiocyanatostilbene-2,2'-disulphonic acid. These features are consistent with currents generated by $\mathrm{ClC}-2$ channels. Our data indicate that functional $\mathrm{CIC}-2$ channels are present in retinal rod bipolar cells and support a role for CIC-2 in maintaining $\mathrm{Cl}^{-}$homeostasis in neurons with ligand-gated chloride channels.

Key words: voltage-gated chloride channel; ClC; ligandgated ion channel; GABA receptor; CNS; retina; rod bipolar cell
The voltage-gated chloride channel $(\mathrm{ClC})$ family in mammals consists of nine different proteins, most of which are of unknown function (Jentsch and Günther, 1997). The third member of this family, ClC-2, is ubiquitously expressed and is associated with a time-dependent, inwardly rectified chloride conductance activated by cell swelling, extracellular acid $\mathrm{pH}$, or membrane hyperpolarization (Gründer et al., 1992; Thiemann et al., 1992; Staley et al., 1996; Jordt and Jentsch, 1997; Schwiebert et al., 1998). Despite the wide distribution of $\mathrm{ClC}$-2, it has been suggested that ClC-2 channels in neurons act in concert with chloride transporters to facilitate neurotransmitter-mediated inhibition (Smith et al., 1995; Staley et al., 1996).

In most mature neurons, outward-directed chloride transporters, such as the potassium-chloride cotransporter or the sodium linked chloride-bicarbonate exchanger, drive the chloride equilibrium potential $\left(E_{\mathrm{Cl}}\right)$ negative relative to the cell resting membrane potential $\left(E_{\mathrm{m}}\right)$ (Thompson and Gähwiler, 1989b; Staley et al., 1996; Jentsch and Günther, 1997; Jarolimek et al., 1999; Rivera et al., 1999). Under this situation, opening of GABA- or glycine-gated chloride channels results in hyperpolarization of the neuron. However, prolonged stimulation of inhibitory recep-

\footnotetext{
Received ; revised ; accepted.

This work was supported by the Deutsche Forschungsgemeinschaft (R.E.), the Reproductive Scientist Development Program through National Institutes of Health Grant 2K12HD00849 (B.J.R.), and National Institutes of Health Grants EY 09531 and DK 48977 (G.R.C.). We thank Drs. R. Smith and K. Staley for the ClC-2 immunoserum, Dr. S. Chu for ClC-2 oligonucleotides, Dr. M. Milewski for help with the confocal microscope, and Drs. J. Wright, W. B. Guggino, and D. Dawson for helpful discussions.

Correspondence should be addressed to Dr. Garry R. Cutting, Institute of Genetic Medicine, CMSC 9-123, The Johns Hopkins University School of Medicine, 600 North Wolfe Street, Baltimore, MD 21287. E-mail: gcutting@jhmi.edu. Copyright (C) 1999 Society for Neuroscience 0270-6474/99/199841-07\$05.00/0
}

tors can reduce the degree of hyperpolarization and can even lead to depolarization because of intracellular chloride accumulation (McCarren and Alger, 1985; Thompson and Gähwiler, 1989a,b; Staley et al., 1995). Furthermore, certain neurons are depolarized by activation of GABA receptors, and it has been shown that $E_{\mathrm{Cl}}$ is positive relative to $E_{\mathrm{m}}$ in these cells (Misgeld et al., 1986; Rohrbough and Spitzer, 1996).

Two observations indicate that $\mathrm{ClC}-2$ channels underlie a noninactivating inwardly rectifying chloride conductance that prevents $E_{\mathrm{C} 1}$ from becoming positive relative to $E_{\mathrm{m}}$ in cells hyperpolarized by inhibitory neurotransmitters (Staley, 1994; Staley et al., 1996). First, pyramidal neurons that are hyperpolarized by GABA expressed ClC-2 channels, whereas dorsal root ganglion (DRG) neurons that are depolarized by GABA lacked ClC-2 expression (Misgeld et al., 1986; Thompson and Gähwiler, 1989b; Staley, 1994; Smith et al., 1995; Rohrbough and Spitzer, 1996). Second, expression of ClC-2 in DRG neurons using an adenoviral vector reduced $E_{\mathrm{C} 1}$ to levels close to $E_{\mathrm{m}}$ and attenuated GABA-mediated depolarization (Staley et al., 1996).

Anatomic, electrophysiological, and molecular studies indicate that activation of $\mathrm{GABA}_{\mathrm{A}}, \mathrm{GABA}_{\mathrm{C}}$, or glycine receptors causes hyperpolarization of retinal bipolar cells $\left(\mathrm{GABA}_{\mathrm{A}}\right.$ receptors: Karschin and Wässle, 1990; Grigorenko and Yeh, 1994; Greferath

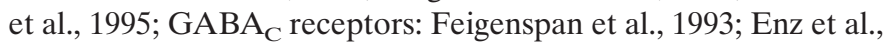
1995; Enz et al., 1996; Euler and Wässle, 1998; Fletcher et al., 1998; glycine receptors: Karschin and Wässle, 1990; Enz and Bormann, 1994; Greferath et al., 1994). However, the expression pattern of voltage-gated chloride channels in the retina is unknown. As a first step to explore the possible role of $\mathrm{ClC}$ channels in visual signal transduction, we analyzed retinal mRNA for members of the $\mathrm{ClC}$ family. Subsequently, the expression of 
Table 1. Oligonucleotides used for the detection of members of the CIC family

\begin{tabular}{|c|c|c|c|}
\hline Primer & Sequence & $\begin{array}{l}\text { Length of } \\
\text { PCR product }\end{array}$ & Reference \\
\hline $\mathrm{P} 1 \mathrm{ClC}-\mathrm{K} 1$ & 5'-TTCAGCATCGAGGTCATGTC-3' & 665 & Uchida et al., 1993 \\
\hline $\mathrm{P} 2 \mathrm{ClC}-\mathrm{K} 1$ & 5'-GCCTCTCCCAAGAGGCG-3' & & \\
\hline $\mathrm{P} 1 \mathrm{ClC}-\mathrm{K} 2$ & 5'-TTCAGCATCGAGGTCATGTC-3' & 661 & Kieferle et al., 1994 \\
\hline $\mathrm{P} 2 \mathrm{ClC}-\mathrm{K} 2$ & 5'-CCCCAAAGAGGCGCCCG-3' & & \\
\hline $\mathrm{P} 1 \mathrm{ClC}-1$ & 5'-CAGCATCTGTGCTGCTGTC-3' & 461 & Steinmeyer et al., 1991 \\
\hline $\mathrm{P} 2 \mathrm{ClC}-1$ & 5'-GTGCTTAGCAAGAAACTGGC-3' & & \\
\hline $\mathrm{P} 1 \mathrm{ClC}-2$ & 5'-CAAGTTCCTCTCCСТCTTTG-3' & 499 & Thiemann et al., 1992 \\
\hline $\mathrm{P} 2 \mathrm{ClC}-2$ & 5'-GAACTGTCCAAAGCCAGGG-3' & & \\
\hline $\mathrm{P} 1 \mathrm{ClC}-3$ & 5'-ССТСТTTCCAAAGTATAGCAC-3' & 552 & Kawasaki et al., 1994 \\
\hline $\mathrm{P} 2 \mathrm{ClC}-3$ & 5'-TTACTGGCATTCATGTCATTTC-3' & & \\
\hline $\mathrm{P} 1 \mathrm{ClC}-4$ & 5'-GGTACATGGCTGAACTCTTC-3' & 297 & Jentsch et al., 1995 \\
\hline $\mathrm{P} 2 \mathrm{ClC}-4$ & 5'-GAGTCATGTTGGGGTCATTG-3' & & \\
\hline $\mathrm{P} 1 \mathrm{ClC}-5$ & 5'-GGAACATCCTGTGCCACTG-3' & 543 & Sakamoto et al., 1996 \\
\hline $\mathrm{P} 2 \mathrm{ClC}-5$ & 5'-AATCACAGAGCTTGGAGGAG-3' & & \\
\hline $\mathrm{P} 1 \mathrm{ClC}-2 \mathrm{~S}$ & 5'-GCCTCTTCTGTGGCAGTCC-3' & $142 / 202$ & Chu et al., 1996 \\
\hline $\mathrm{P} 2 \mathrm{ClC}-2 \mathrm{~S}$ & 5'-ACCCGCTTCAGCTTGC-3' & & \\
\hline
\end{tabular}

$\overline{\mathrm{P} 1 \mathrm{ClC}-2 \mathrm{~S} \text { and P2 ClC-2S were used to analyze different splice variants of ClC-2. P1, Sense primer, P2, antisense primer. }}$

ClC-2 was studied in detail, using ClC-2-specific antibodies in combination with colocalization techniques. Patch-clamp experiments were performed on dissociated retinal neurons to verify the results of the immunocytochemical studies. We conclude that rod bipolar cells express functional ClC-2 chloride channels.

\section{MATERIALS AND METHODS}

cDNA synthesis and PCR. Five micrograms of rat retina poly $\left(\mathrm{A}^{+}\right) \mathrm{RNA}$ (Clontech, Palo Alto, CA) were incubated for $30 \mathrm{~min}$ at $37^{\circ} \mathrm{C}$ with $50 \mathrm{U}$ of DNaseI (Boehringer Mannheim, Mannheim, Germany) and $40 \mathrm{U}$ of RNasin (Boehringer Mannheim) in a final volume of $100 \mu \mathrm{l}$ to remove possible contamination from chromosomal DNA. To remove the enzyme, acid phenol extraction and ethanol precipitation was performed by adding $16 \mu \mathrm{l}$ of $2 \mathrm{M}$ sodium acetate, $\mathrm{pH} 4.0,100 \mu \mathrm{l}$ of acid phenol, and 50 $\mu \mathrm{l}$ of chloroform/isoamylalcohol (49:1) following the protocol of Chomczynski and Sacchi (1987). All chemicals were purchased from Sigma (St. Louis, MO). cDNA synthesis was performed in $40 \mu \mathrm{l}$ of cDNA synthesis buffer, containing $50 \mathrm{~mm}$ Tris- $\mathrm{HCl}$, $\mathrm{pH} 8.3,3 \mathrm{~mm} \mathrm{MgCl}_{2}, 75 \mathrm{~mm} \mathrm{KCl}, 10$ $\mathrm{mM}$ dithiothreitol, and $0.5 \mathrm{~mm}$ each $\mathrm{dNTP}, 250 \mathrm{ng}$ of $\mathrm{p}(\mathrm{dN})_{6}, 40 \mathrm{U}$ of RNasin (Boehringer Mannheim), and $800 \mathrm{U}_{\text {of SuperscriptII RNaseH }}{ }^{-}$ reverse transcriptase (Life Technologies, Grand Island, NY). Incubation times were $15 \mathrm{~min}$ at room temperature followed by $2 \mathrm{hr}$ at $42^{\circ} \mathrm{C}$. For $\mathrm{PCR}$, oligonucleotides specific for seven members of the rat $\mathrm{ClC}$ family were used (Table 1). Amplification was performed with $100 \mathrm{ng}$ of reversetranscribed RNA in $50 \mu \mathrm{l}$ of PCR buffer [20 mM Tris-HCl, pH 8.0, $50 \mathrm{~mm}$ $\mathrm{KCl}, 1.5 \mathrm{~mm} \mathrm{MgCl}, 0.2 \mathrm{~mm}$ dNTPs, $0.2 \mu \mathrm{M}$ each primer, and $5 \mathrm{U}$ of Taq-polymerase (Life Technologies)] using a programmable thermocycler (Perkin-Elmer Cetus, Norwalk, CT) with the following parameters: $94^{\circ} \mathrm{C}$ for $3 \mathrm{~min}$ followed by 30 cycles at $94^{\circ} \mathrm{C}$ for $45 \mathrm{sec}, 58^{\circ} \mathrm{C}$ for $60 \mathrm{sec}$, $72^{\circ} \mathrm{C}$ for $45 \mathrm{sec}$, and a final incubation at $72^{\circ} \mathrm{C}$ for $10 \mathrm{~min}$. To detect splice variants of $\mathrm{ClC}-2$, annealing was performed at $55^{\circ} \mathrm{C}$. Ten microliters of each PCR product were separated on a $1.5 \%$ agarose gel and stained with ethidium bromide. Controls were treated as described above, except adding reverse transcriptase. To verify the identity of the DNA fragments, PCR solutions were purified using Microcon-100 spin columns (Amicon, Beverly, MA) or geleluted (Qiagen, Hilden, Germany) and subjected to dideoxy sequencing (Sanger, 1977).

Immunohistochemistry. After intramuscular injection of ketamine (87 $\mathrm{mg} / \mathrm{kg}$; Sigma) and xylazine (13 mg/kg; Sigma), the deeply anesthetized adult Wistar rats were euthanized via transcardiac puncture and exsanguination. The eyes were enucleated, and the lens, cornea, and vitreous body were removed. Eyecups were fixed for $1 \mathrm{hr}$ in $4 \%$ paraformaldehyde, cryoprotected in $30 \%$ sucrose, embedded in O.C.T. compound (Sakura Finetek, Torrance, CA), and frozen in isopentane chilled with dry ice. Subsequently, $12 \mu \mathrm{m}$ cryosections were collected on siliconized slides. Immunostaining was performed using the indirect fluorescence method with rat anti ClC-2 (1:100) (Staley et al., 1996) and mouse anti-PKC (1:50; Amersham Pharmacia Biotech, Arlington Heights, IL) as primary antibodies and goat anti-rat conjugated to $\mathrm{Cy} 3(1: 1000$; Sigma) and goat anti-mouse conjugated to FITC (1:50; Sigma) as secondary antibodies. For double-label experiments, sections were first incubated in a mixture of primary antibodies, followed by a mixture of secondary antibodies. Controls were prepared by using only secondary antibodies or by omitting one of the two primary antibodies. In this case, only immunoreactivity of the remaining primary antibody was detected. Immunofluorescence was accomplished using an epifluorescence microscope (Axiophot; Zeiss, Jena, Germany) equipped with a $40 \times 1.3$ fluorite objective, a filter wheel (Sutter, Novato, CA), a cooled coupling device (CCD camera CH350; Photometrics, Tucson, AZ), and Metamorph software (Universal Imaging Corp., West Chester, PA). Horizontal sections were analyzed using a confocal laser-scanning microscope (LSM 410; Zeiss) and Zeiss LSM software (version 3.80). Images were reproduced with Adobe Photoshop (Adobe Systems, San Jose, CA) and a color printer (NP-1600M; Codonics, Middleburg Heights, OH).

Cell preparation and electrophysiological recordings. Retinas of adult Wistar rats ( 8 weeks) were dissociated using a combination of enzymatic and mechanical procedures as described previously (Huba and Hofmann, 1988; Karschin and Wässle, 1990). One hour after plating on glass coverslips coated with poly-L-lysine (Sigma) and concanavalin A (Sigma), bipolar cells were visually identified under phase-contrast optics of an inverted microscope (Nikon, Melville, NY) with a CF plan flour 20× objective. Cells were continuously superfused with an extracellular bath solution at a rate of $1 \mathrm{ml} / \mathrm{min}$ containing (in $\mathrm{mm}$ ): $137 \mathrm{NaCl}, 5.4 \mathrm{KCl}, 1.8$ $\mathrm{CaCl}_{2}, 1 \mathrm{MgCl}_{2}$, and 5 HEPES, pH 7.4. $\mathrm{NaCl}$ was replaced by $\mathrm{NaI}$ and sodium gluconate in anion selectivity experiments. Patch pipettes were made from borosilicate glass (Warner Instruments, Hamden, CT) using a two-stage electrode puller (Narashige, East Meadow, NY) and had pipette resistances of 3.7-5.2 $\mathrm{M} \Omega$ (mean of $4.3 \mathrm{M} \Omega ; n=5$ ) when filled with an intracellular solution containing (in $\mathrm{mM}$ ): $120 \mathrm{CsCl}, 20 \mathrm{TEA}-\mathrm{Cl}$, $1 \mathrm{CaCl}_{2}, 2 \mathrm{MgCl}_{2}, 11$ EGTA, and $10 \mathrm{HEPES}, \mathrm{pH}$ 7.2. Electrode holder and head stage were mounted on a piezo-electric remote-controlled device attached to a three-dimensional mechanical micromanipulator (Burleigh Instruments, Fishers, NY). Membrane currents were recorded in the whole-cell configuration of the patch-clamp method (Hamill et al., 1981) using an Axopatch amplifier (Axon Instruments, Foster City, CA) and PCLAMP 6.0 software (Axon Instruments). Currents were low-pass filtered at $2 \mathrm{kHz}$ (four-pole Bessel filter) and sampled with $20 \mathrm{~Hz}$. The recorded data were corrected for errors resulting from series resistance, estimated to be in the range of $15 \mathrm{M} \Omega$ (two to five times the pipette resistance) (Marty and Neher, 1995) and from liquid junction potential, calculated to be $+3.37 \mathrm{mV}$ for $\mathrm{NaCl},-2.42 \mathrm{mV}$ for $\mathrm{NaI}$, and $-7.31 \mathrm{mV}$ for sodium gluconate (Barry, 1994). Leak subtraction was not applied, because the data presented in this paper are qualitative in nature. 

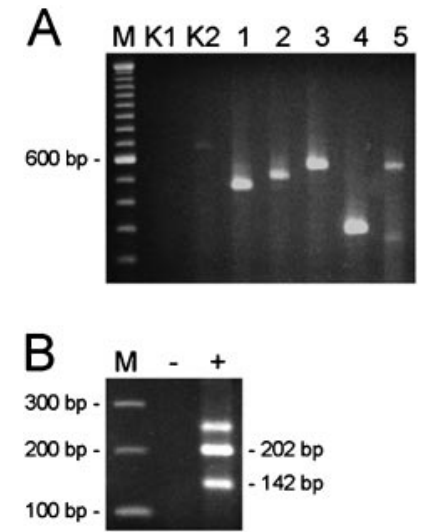

Figure 1. Expression of RNA encoding voltage-gated chloride channels in the rat retina. Ethidium bromide stained RT-PCR products amplified from rat retina RNA using primers specific for seven different $\mathrm{ClC}$ genes $(A)$ and primers flanking exon 20 of the rat $\mathrm{ClC}-2$ gene $(B)$. The identity of all PCR products was determined by DNA sequencing. $A$, The $\mathrm{ClC}$ type is indicated above the agarose gel, and the $600 \mathrm{bp}$ fragment of a 100 bp ladder (lane $M$ ) is shown on the left. The faintly stained fragments in lane $K 2$ and lane 5 are attributable to nonspecific amplification. $B$, The exon 20 splice variant of rat ClC-2 was detected in retinal RNA (+ lane). The expected sizes of fragments amplified from ClC-2 transcripts with exon 20 (202 bp) and without exon 20 (142 bp) are indicated on the right. The fragment without an indicated size is because of formation of a heteroduplex of the two smaller DNA fragments. Absence of amplified product in the reaction without reverse transcriptase (- lane) excluded contamination.

$\mathrm{CdSO}_{4}, 4,4^{\prime}$-diisothiocyanatostilbene-2,2' -disulphonic acid (DIDS), NaI, and sodium gluconate (all from Sigma) were applied in the bath solution with the U-tube application system (Bormann, 1992). To generate current-voltage plots, amplitude values measured at $200 \mathrm{msec}$ were normalized to 1 for each cell and plotted against the applied voltage. Error bars represent \pm SEM. A modified version of the Goldman-HodginKatz equation was used to calculate permeation ratios $\left(\mathrm{p}_{\text {Anion }} / \mathrm{p}_{\text {Chloride }}=\right.$ $\left(e^{-\left(E_{\text {rev }} * F / R T\right)}-\left([\text { Chloride }]_{\mathrm{o}} /[\text { Chloride }]_{\mathrm{i}}\right)\right) /\left([\text { Anion }]_{\mathrm{o}} /[\text { Chloride }]_{\mathrm{i}}\right)$.

\section{RESULTS}

\section{Expression of voltage-gated chloride channels in the rat retina}

The presence of mRNA transcripts encoding seven members of the $\mathrm{ClC}$ family in the adult rat retina was studied using reverse transcription (RT)-PCR. Single strand cDNA obtained after reverse transcription of retinal mRNA was amplified with oligonucleotides specific for the seven $\mathrm{ClC}$ genes (Table 1). DNA fragments were amplified from ClC-1,-2,-3,-4, and -5 mRNA transcripts but not from $\mathrm{ClC}-\mathrm{K} 1$ or $\mathrm{ClC}-\mathrm{K} 2$ (Fig. $1 A$ ). Alternative splicing of $\mathrm{ClC}-2$ in rat brain has been reported. Skipping of exon 20 produced mRNA transcripts that were 60 nucleotides shorter (Chu et al., 1996; Chu and Zeitlin, 1997). DNA fragments of the expected size for the exon 20 splice variant were amplified from rat retina (Fig. $1 B$ ). For all PCR experiments, control reactions without adding reverse transcriptase excluded contamination.

\section{Immunohistochemical localization of CIC-2 in rod bipolar cells}

A polyclonal immunoserum raised in rabbit that specifically recognizes C1C-2 (Staley et al., 1996) was applied to vertical cryostat sections of the adult rat retina. Immunoreactivity could be detected in all retinal layers (Fig. 2A). Cell bodies in the outer nuclear layer (ONL) were faintly labeled, whereas cell bodies present in the inner nuclear layer (INL) and ganglion cell layer

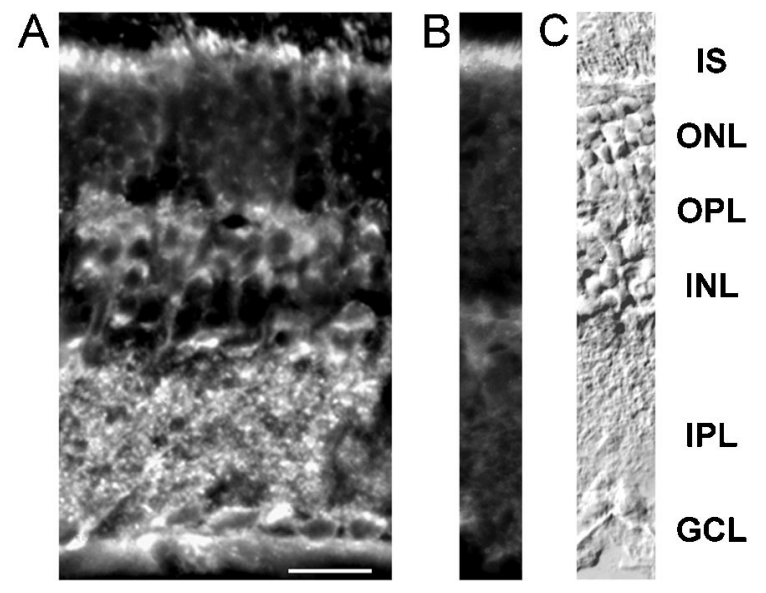

Figure 2. Immunohistochemical detection of $\mathrm{ClC}-2$ in the rat retina. $A$, A fluorescence micrograph of a vertical cryostat section through the rat retina was incubated with antibodies specific for $\mathrm{ClC}-2$ and visualized using secondary antibodies coupled to Cy3. Immunofluorescence could be seen throughout the retina, most prominent at cell bodies present in the outer half of the INL and in the IPL. Scale bar, $25 \mu \mathrm{m}$. B, Control experiment in which only the secondary antisera was used. Nonspecific staining of photoreceptor inner segments can be seen. $C$, Retinal layers are shown using Nomarski optics. IS, Inner segments of photoreceptors; $O N L$, outer nuclear layer; $O P L$, outer plexiform layer; $I N L$, inner nuclear layer; $I P L$, inner plexiform layer; $G C L$, ganglion cell layer.

(GCL) were intensely stained. Within the INL, ClC-2 immunoreactivity was visible as bright regions in cell bodies lying at the outer half of the INL, presumably being bipolar cell bodies. In addition, fluorescence could be detected in both the outer plexiform layer (OPL) and the inner plexiform layer (IPL). The strong staining of photoreceptor inner segments was nonspecific, because it was also visible in sections that were incubated without primary antibodies (Fig. $2 B$ ). To indicate the position of retinal layers, a Nomarski photograph is shown in Figure $2 C$.

To determine which type of neurons stained brightly in the outer half of the INL, we performed double-immunofluorescence experiments. Labeling for C1C-2 was visualized with secondary antibodies coupled to $\mathrm{Cy} 3$ (Fig. $3 A$, red fluorescence). Intense staining was visible in the outer half of the INL, as well as throughout the IPL. The same section was also incubated with an antibody against the $\alpha$ isoform of PKC, which is used to identify rod bipolar cells (Greferath et al., 1990). Binding of this antibody was visualized with secondary antibodies coupled to FITC (Fig. $3 B$, green fluorescence). Rod bipolar cell bodies were seen in the outer half of the INL. Their dendrites terminated in the OPL, and their axons proceeded vertically to the lower border of the IPL in which they ended in a broad band of varicose swellings. Double exposure of this section superimposed the red staining for $\mathrm{ClC}-2$ in the upper half of the INL on nearly every green-labeled rod bipolar cell body. The resulting yellow signals were visible as bright regions in the upper part of the INL and appeared to be within the rod bipolar cell bodies (Fig. $3 C$ ). In addition, intense ClC-2 immunoreactivity was colocalized with the axon terminal systems of rod bipolar cells in the IPL (stars).

Further studies were performed to determine the location of the ClC-2 immunoreactivity in the INL and the IPL. An enlarged vertical section of the outer half of the INL is shown in Figure $4 A$. Every rod bipolar cell body (identified by green $\mathrm{PKC}$ immunoreactivity) was also labeled with the ClC-2 antiserum, seen as intense costaining (yellow). ClC-2 was also present on 


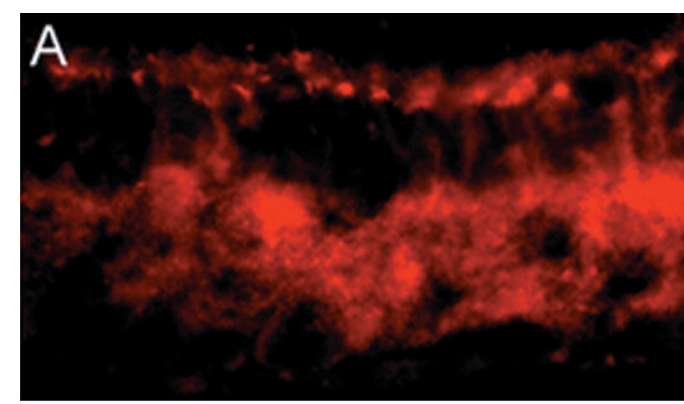

OPL

INL

IPL.

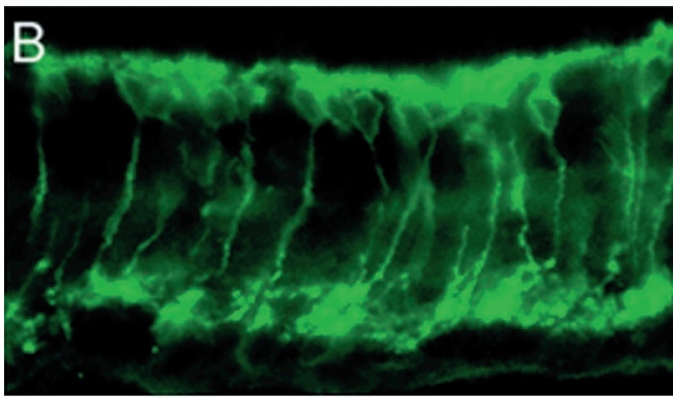

OPL

INL

JPL

GCL

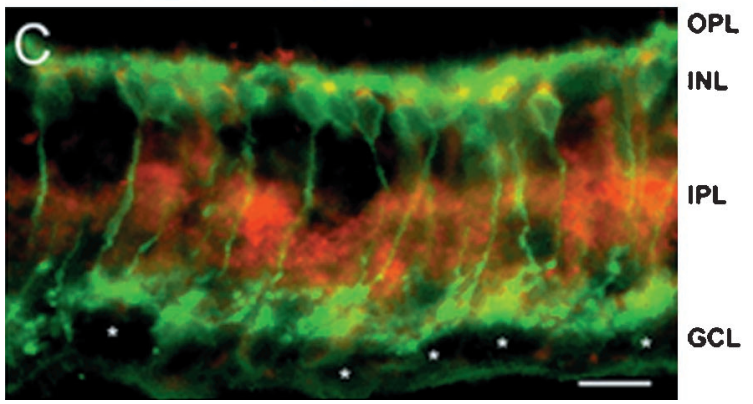

Figure 3. Localization of C1C-2 on rod bipolar cells. A, Fluorescence micrographs of a vertical cryostat section labeled with a $\mathrm{ClC}$-2-specific antiserum (Cy3-coupled secondary antisera, red fluorescence). B, Incubation of the same section as in $A$ with antisera specific for the $\alpha$ subunit of PKC, which identifies rod bipolar cells (FITC-coupled secondary antisera, green fluorescence). $C$, Double exposure of the section revealed staining for $\mathrm{ClC}-2$ on the upper half of rod bipolar cell bodies (yellow fluorescence) and on rod bipolar cell axon terminal systems (stars). Scale bar, $25 \mu \mathrm{m}$.

neurons other than rod bipolar cells (Fig. 4A, star). To evaluate whether the $\mathrm{ClC}-2$ immunoreactivity on rod bipolar cell bodies was localized to the membrane or whether the protein was present in intracellular structures, a horizontal plane of a doublelabeled rod bipolar cell body was visualized by confocal laserscanning microscopy (Fig. $4 B$ ). Superimposure of the PKC immunoreactivity (left, green fluorescence) with the ClC-2 staining (middle, red fluorescence) suggested that $\mathrm{ClC}-2$ is localized in or near the cell membrane of rod bipolar cell bodies (right, yellow fluorescence). An enlarged view of the IPL is shown in Figure $4 C$. The left shows vertically oriented axons of rod bipolar cells terminating in their terminal systems at the lower border of the IPL (green fluorescence). The $\mathrm{ClC}-2$ immunofluorescence of the same section is shown in the right of Figure $4 C$ (red fluorescence). Colocalization of rod bipolar cell axon terminals with $\mathrm{ClC}-2$ staining was evident (stars). In summary, ClC-2 seems to be expressed at axon-terminal systems of rod bipolar cells, thus being in the vicinity of GABA and glycine receptors. In addition, we found $\mathrm{ClC}-2$ to be expressed in surprisingly high concentrations in rod bipolar cell bodies, most likely present in the membrane of these neurons.

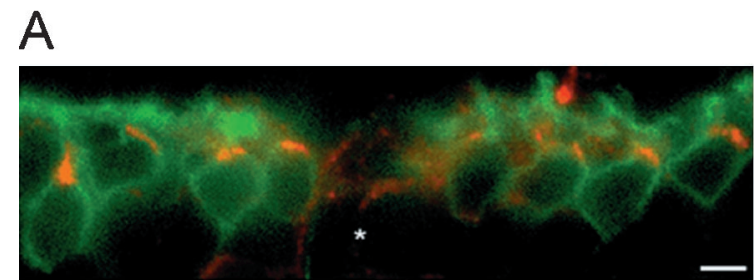

B
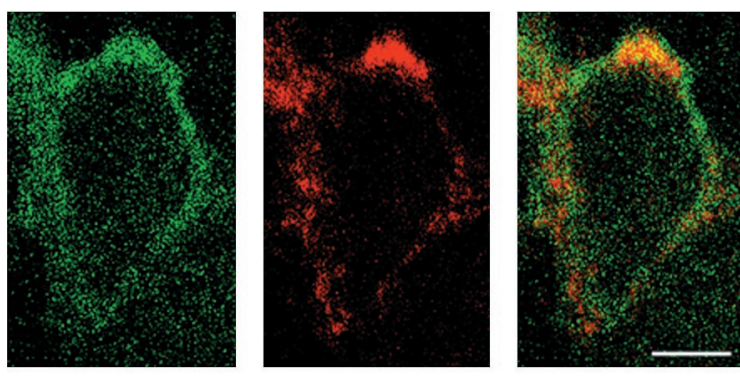

C
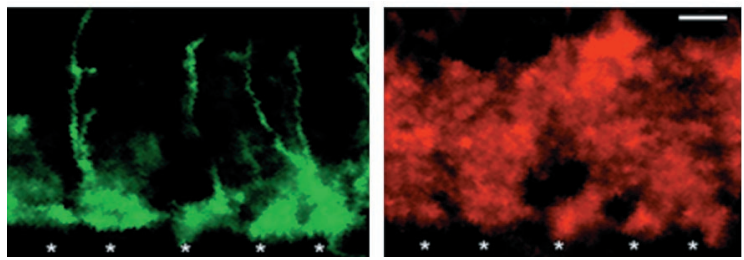

Figure 4. Subcellular distribution of ClC-2 on rod bipolar cells. $A$, Enlarged view of a vertical cryostat section immunolabeled as in Figure 3. Cell bodies of rod bipolar cells were located in the outer half of the inner nuclear layer (green fluorescence). ClC-2 immunoreactivity (red fluorescence) was present on every cell body, resulting in yellow signals. In addition, ClC-2 staining outlined other cells (star). B. Horizontal singlesection confocal fluorescence micrographs of a rod bipolar cell body double-immunolabeled as described in Figure 3. PKC immunoreactivity was predominantly localized to the cell membrane (left, green fluorescence). Expression of $\mathrm{ClC}-2$ is shown in the middle (red fluorescence). The double exposure demonstrated that $\mathrm{ClC}-2$ immunoreactivity seemed to be mostly present within or near the cell membrane (right, yellow). $C$, Enlarged view of the lower border of the IPL of double-labeled vertical cryostat sections. Axon terminal systems of rod bipolar cells were doubleimmunolabeled with antibodies recognizing PKC (left, green fluorescence). ClC-2 immunoreactivity (red fluorescence) was present at identical positions (stars). Furthermore, ClC-2 immunoreactivity was observed at other regions within the IPL. Scale bars: $A, C, 10 \mu \mathrm{m} ; B, 5 \mu \mathrm{m}$.

\section{Hyperpolarization-activated chloride currents in rod bipolar cells}

To investigate whether functional ClC-2 chloride channels are present in cell membranes of rod bipolar cells, we performed whole-cell patch-clamp studies on isolated rod bipolar cells. It has been shown previously that cells in retinal dissociates that have the appearance of bipolar cells (Fig. $3 B$ ) are rod bipolar cells, because they can be stained with an antibody against the $\alpha$ subunit of PKC (Greferath et al., 1990; Karschin and Wässle, 1990). Rod bipolar cells were visually identified under an inverted microscope, and voltage-activated currents were recorded using a specific protocol: initial depolarization from 0 to $+40 \mathrm{mV}$, than voltage steps in $-20 \mathrm{mV}$ increments to a potential of $-140 \mathrm{mV}$ (Fig. 5, left). Maximal currents at $-140 \mathrm{mV}$ were between 1000 and $3000 \mathrm{pA}$. A representative current tracing is shown in Figure 5 (middle). At negative voltages, the chloride channel opened in a time-dependent manner over a $250 \mathrm{msec}$ interval and showed inward rectification, characteristics typical of $\mathrm{ClC}-2$ recorded in 


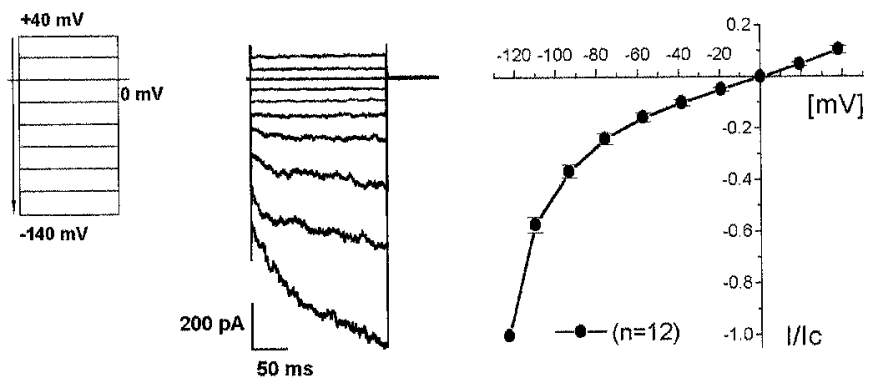

Figure 5. Hyperpolarization-activated chloride currents on isolated rod bipolar cells. A hyperpolarizing voltage step protocol (left) generated inwardly rectified, noninactivating currents from an isolated rod bipolar cell (middle). Data recorded from 12 different bipolar cells are summarized in a current-voltage plot (right). The current amplitudes have been normalized $\left(I / I_{\mathrm{c}}\right)$ to the currents at $-140 \mathrm{mV}\left(I_{\mathrm{c}}\right.$; see Materials and Methods for details).

mammalian cells (Carew and Thorn, 1996; Ferroni et al., 1997; Park et al., 1998; Schwiebert et al., 1998). To compare currentvoltage relationships of different bipolar cells, current values for each cell were normalized by dividing the current recorded at each voltage step by the current recorded at $-140 \mathrm{mV}$. Normalized data from 12 different cells are shown in a current-voltage plot (Fig. 5, right). Inward rectification of the observed chloride conductance was observed at potentials negative to $-60 \mathrm{mV}$.

To characterize the nature of the observed currents, hyperpolarization-activated currents were recorded in bath solutions containing different anions. The relative anion selectivity for ClC-2 has been shown to be $\mathrm{Cl}^{-}>\mathrm{I}^{-}>$gluconate (Thiemann et al., 1992; Ferroni et al., 1997; Jordt and Jentsch, 1997; Clark et al., 1998; Schwiebert et al., 1998). When $137 \mathrm{~mm} \mathrm{NaCl}$ was substituted with sodium iodide or sodium gluconate, the amplitudes of the recorded currents decreased in the order $\mathrm{Cl}^{-}$ $>\mathrm{I}^{-}>$gluconate at all potentials (Fig. $6 \mathrm{~A}$ ). Normalized data are shown in a current-voltage plot. Mean reductions at $-100 \mathrm{mV}$ were $38.6 \pm 10.7 \%$ (iodide) and $60.1 \pm 3.3 \%$ (gluconate) and were statistically significant (chloride-iodide, $p=3.5 \times 10^{-4}$; iodide-gluconate, $\left.p=3.8 \times 10^{-2}\right)$. The reversal potentials $\left(E_{\mathrm{rev}}\right)$ were $+0.29 \pm 0.4 \mathrm{mV}$ for symmetrical chloride, $+3.3 \pm 0.25 \mathrm{mV}$, and $+16.6 \pm 4.2 \mathrm{mV}$ after substituting $137 \mathrm{~mm}$ chloride with iodide or gluconate. From the mean values, permeation ratios relative to chloride were calculated for iodide $(0.85)$ and for gluconate (0.47).

To further characterize the hyperpolarization-activated currents in isolated bipolar cells, $\mathrm{Cd}^{2+}$ or DIDS were applied in the external solution. Cadmium has been shown to be a potent reversible inhibitor of $\mathrm{ClC}$-2-mediated chloride currents, whereas DIDS only minimally affects ClC-2 currents (Madison et al., 1986; Chesnoy-Marchais and Fritsch, 1994; Fritsch and Edelmann, 1996; Ferroni et al., 1997; Clark et al., 1998; Schwiebert et al., 1998). Application of $500 \mu \mathrm{M} \mathrm{Cd}^{2+}$ reduced the voltageactivated current by $86.4 \pm 2.7 \%$ at $-120 \mathrm{mV}$ (Fig. 6B). In contrast, the application of $500 \mu \mathrm{M}$ DIDS had a minor effect on the recorded current traces $(-26.3 \pm 10.1 \%$ at $-120 \mathrm{mV})$. Normalized data from five different cells are shown in a currentvoltage plot. Thus, rod bipolar cells generated time-dependent inwardly rectifying currents at hyperpolarizing voltages that showed anion-selectivity $\left(\mathrm{Cl}^{-}>\mathrm{I}^{-}>\right.$gluconate $)$, sensitivity to $\mathrm{Cd}^{2+}$, and minimal inhibition by DIDS.

\section{DISCUSSION}

Very little is known of the expression pattern of voltage-gated chloride channels in the retina. Using RT-PCR, we detected transcripts for $\mathrm{ClC}-1,-2,-3,-4$, and -5 in the adult rat retina. $\mathrm{ClC}-1$ is considered to be muscle-specific; thus, our observations on the expression of $\mathrm{ClC}-1$ outside muscle suggests a broader distribution of this channel than previously thought. Indeed, $\mathrm{ClC}-1$ has also been detected in hair cells of the rat cochlea (Kawasaki et al., 1999). Considering the potential importance of ClC-2 in inhibitory neurotransmission, we decided to perform an extensive study on its cellular distribution in the retina. Incubation of vertical cryostat sections of retina with $\mathrm{ClC}$-2-specific antibodies revealed the presence of $\mathrm{ClC}-2$ protein on the cell bodies of all nuclear layers, as well as in both synaptic layers, consistent with the wide tissue distribution of ClC-2 (Thiemann et al., 1992). However, intense staining was consistently noted in the outer half of the INL that colocalized with PKC-stained rod bipolar cells.

Confocal microscopy revealed that the ClC-2 staining appeared to be in, or near, the cell membranes of rod bipolar cells. ClC-2 has been found in the proximity of cell membranes in airway epithelia of the rat and human embryonic kidney cells (HEK 293) and in secretory granules at the apical pole of pig pancreatic cells (Murray et al., 1995; Carew and Thorn, 1996; Park et al., 1998). In the IPL of the rat retina, axon terminals of rod bipolar cells were intensely stained by the $\mathrm{ClC}-2$ antibodies. Many subunits of glycine and GABA receptors are present at the axon terminal systems of these cells (Karschin and Wässle, 1990; Greferath et al., 1995; Enz et al., 1996). Therefore, ClC-2 seems to be present in a region of bipolar cells in which massive chloride influx is predicted to occur. However, we cannot rule out the possibility that localization in the IPL is a result of expression of ClC-2 on amacrine cells that form reciprocal synapses with bipolar cell terminals. This issue might be solved using electron microscopy.

Patch-clamp experiments were performed on single rod bipolar cells to corroborate the anatomical localization of $\mathrm{ClC}-2$ to these neurons. The isolated cells exhibited time-dependent inwardly rectified currents that activated within milliseconds at hyperpolarizing membrane potentials. The anion selectivity $\left(\mathrm{Cl}^{-}>\mathrm{I}^{-}>\right.$ gluconate) of these currents indicated that a chloride selective ion channel was responsible for a substantial fraction of the currents. Furthermore, the observed reversal potential $\left(E_{\text {rev }}\right)$ in symmetrical chloride $(+0.3 \mathrm{mV})$ was close to the predicted $E_{\text {rev }}$ for a chloride current under these conditions $(0 \mathrm{mV})$. Substitution of extracellular chloride with iodide or gluconate caused a shift of $E_{\text {rev }}$ to positive voltages as expected, but the magnitude of the shift was less than predicted by the Nernst equation. The muted shift in reversal potential may be caused by inactivation of $\mathrm{ClC}-2$ at depolarizing voltages, as reported previously (Jordt and Jentsch, 1997). This concept is supported by the observation that ClC-2 channels activated by acidic $\mathrm{pH}$ remain open at positive voltages and display more substantial shifts of $E_{\text {rev }}$ in iodide and gluconate solutions (Jordt and Jentsch, 1997; Schwiebert et al., 1998).

The characteristics and anion selectivity of the chloride currents were consistent with those reported previously for C1C-2. Exchange of extracellular chloride with other anions reduced the current amplitudes at negative and positive membrane potentials, indicating an effect that was independent of the direction of ion flow (Thiemann et al., 1992; Ferroni et al., 1997; Clark et al., 1998; Schwiebert et al., 1998). Furthermore, ClC-2 expressed in mammalian cells has been shown to activate in milliseconds, as observed in the rat bipolar cells (Carew and Thorn, 1996; Ferroni 
Figure 6. Electrophysiological characterization of hyperpolarization-activated currents in rod bipolar cells. $A$, Representative current tracings of a single rod bipolar cell recorded in different anionic solutions. Current amplitudes and the degree of inward rectification decreased in $\mathrm{NaI}$, further decreased in $\mathrm{Na}$ gluconate, and returned to original levels in $\mathrm{NaCl}$. The current-voltage plot on the right represents calculated mean data. Currents were normalized $\left(I / I_{\mathrm{c}}\right)$ using current amplitudes at $-120 \mathrm{mV}$ in $\mathrm{NaCl}\left(I_{\mathrm{c}}\right)$. The voltage protocol was the same as described in Figure 5, except that the applied potentials ranged from +60 to $-120 \mathrm{mV}$. $B$, Representative current tracings of a single rod bipolar cell exposed to extracellular DIDS or $\mathrm{CdSO}_{4}$. The first and fourth recordings were performed in symmetrical chloride solutions alone. The voltage-activated currents were partially inhibited by the application of 500 $\mu \mathrm{M}$ DIDS and substantially reduced by $500 \mu \mathrm{M} \mathrm{CdSO}_{4}$. Inhibition of each compound was reversible. The current-voltage plot of normalized mean data are shown at the right. Currents have been normalized as described in $A$.

et al., 1997; Schwiebert et al., 1998). In contrast, mammalian forms of ClC-2 have considerably slower activation kinetics when expressed in Xenopus oocytes (Thiemann et al., 1992; Jordt and Jentsch, 1997). To further characterize the observed chloride conductance, we applied $\mathrm{Cd}^{2+}$ and DIDS, two compounds used to study ClC-2 in other cell systems (Ferroni et al., 1997; Clark et al., 1998; Schwiebert et al., 1998). Extracellular $\mathrm{Cd}^{2+}$ substantially reduced the voltage-activated chloride current, whereas DIDS had a minor effect, most likely because of its negative charge, consistent with previous studies of ClC-2 (Ferroni et al., 1997; Clark et al., 1998; Schwiebert et al., 1998). Therefore, our electrophysiological studies appear consistent with ClC-2 immunoreactivity in, or near, the cell membrane of rod bipolar cells (Fig. $4 B$ ) and support the idea that at least a fraction of $\mathrm{ClC}-2$ protein is located within the membrane.

The hyperpolarization-activated currents we observed in the rod bipolar cells have characteristics similar to a potassium conductance studied by Karschin and Wässle (1990). The authors reported that addition of cesium in the patch pipette blocked the potassium current completely. Although shape and activation characteristics of the potassium currents were similar to the traces presented in this paper, it is unlikely that the conductance we described was caused by potassium. First, all recordings were performed with 120 $\mathrm{mm} \mathrm{CsCl}$ and $20 \mathrm{~mm}$ TEA-Cl in the patch-pipette; thus, potassiummediated currents should be completely blocked. Second, all recordings were performed with symmetrical chloride concentrations without potassium inside the cell. Under these conditions, a potassium current would reverse at a very positive voltage. In contrast, the observed reversal potential of our currents was close to $0 \mathrm{mV}$, consistent with the predicted reversal potential of a chloride current under our recording conditions. We cannot, however, exclude the possibility that a minor portion of the voltage-activated current could be carried by an inwardly rectified potassium current because of an incomplete block by $\mathrm{Cs}^{+}$and $\mathrm{TEA}^{+}$, and/or by a $\mathrm{Cd}^{2+}$ sensitive nonselective cation conductance.

Among retinal neurons, only rod bipolar cells express three ligand-gated chloride channels (glycine, $\mathrm{GABA}_{\mathrm{A}}$, and $\mathrm{GABA}_{\mathrm{C}}$, receptors). It has been shown that GABA and glycine can be coreleased from individual synaptic vesicles in interneuron-- motoneuron synapses of the rat spinal cord, producing simultaneous activation of GABA and glycine receptors (Jonas et al., 1998). Although the same phenomenon has not been observed in the retina, simultaneous release of both neurotransmitters may occur at a single synapse using different vesicles. Thus, GABA and glycine receptors might be activated simultaneously, which could result in a substantial chloride influx into rod bipolar cells. Reduction of the chloride gradient could lower the inhibitory effect of GABA and glycine on the bipolar cells (Adams and Brown, 1975; Barker and Ransom, 1978; Segal and Barker, 1984).

Our results suggest that two mechanisms operate to maintain the chloride gradient and, in turn, the inhibitory effect of GABA and glycine on retinal bipolar cells. First, outward-directed chloride transporters, such as KCC2, could actively transport chloride out of cells to establish a strong inward driving force for chloride (Jarolimek et al., 1999; Rivera et al., 1999). Indeed, it has been shown that bipolar cells in primary cultures of the chick retina express the KCC2 isoform of the potassium-chloride cotransporter (Williams et al., 1999). Localization of functional ClC-2 channels to bipolar cells in this report suggests that a second mechanism may operate in situations of substantial chloride influx. Based on the proposition that ClC-2 channels clamp $E_{\mathrm{Cl}}$ at or near $E_{\mathrm{m}}$ in cortical neurons, it is possible that these channels play the same role in retinal neurons (Smith et al., 1995; Staley et al., 1996). In this way, ClC-2 could act as a "safety" valve for chloride ions. The characteristics of $\mathrm{ClC}-2$, inwardly rectified chloride channels that open at hyperpolarizing membrane potentials without time-dependent inactivation would be well suited for this task.

\section{REFERENCES}

Adams PR, Brown DA (1975) Actions of gamma-aminobutyric acid on sympathetic ganglion cells. J Physiol (Lond) 250:85-120.

Barker JL, Ransom BR (1978) Amino acid pharmacology of mammalian central neurons grown in tissue culture. J Physiol (Lond) 280:331-354.

Barry PH (1994) JPCalc, a software for calculating liquid junction potential corrections in patch-clamp, intracellular epithelial and bilayer measurements and for correcting junction potential measurements. J Neurosci Methods 51:107-116.

Bormann J (1992) U-tube drug application. In: Practical electrophysiological methods (Kettenmann H, Grantyn R, eds), pp 136-140. New York: Wily-Liss. 
Carew MA, Thorn P (1996) Identification of ClC-2-like chloride currents in pig pancreatic acinar cells. Pflügers Arch 433:84-90.

Chesnoy-Marchais D, Fritsch J (1994) Activation by hyperpolarization and atypical osmosensitivity of $\mathrm{a} \mathrm{Cl}^{-}$current in rat osteoblastic cells. J Membr Biol 140:173-188.

Chomczynski P, Sacchi N (1987) Single-step method of RNA isolation by guanidinium thiocyanate-phenol-chloroform extraction. Anal Biochem 162:156-159.

Chu S, Zeitlin PL (1997) Alternative mRNA splice variants of the rat ClC-2 chloride channel gene are expressed in lung: genomic sequence and organization of ClC-2. Nucleic Acids Res 25:4153-4159.

Chu S, Murray CB, Liu MM, Zeitlin PL (1996) A short ClC-2 mRNA transcript is produced by exon skipping. Nucleic Acids Res 24:3453-3457.

Clark S, Jordt S-E, Jentsch TJ, Mathie A (1998) Characterization of the hyperpolarization-activated chloride current in dissociated rat sympathetic neurons. J Physiol (Lond) 506:665-678.

Enz R, Bormann J (1994) Expression of glycine receptor subunits and gephyrin in single bipolar cells of the rat retina. Vis Neurosci 12:501-507.

Enz R, Brandstätter JH, Hartveit E, Wässle H, Bormann J (1995) Expression of GABA receptor subunits $\rho 1$ and $\rho 2$ in the retina and brain of the rat. Eur J Neurosci 7:1495-1501.

Enz R, Brandstätter JH, Wässle H, Bormann J (1996) Immunocytochemical localization of $\mathrm{GABA}_{\mathrm{C}}$ receptor $\rho$ subunits in the mammalian retina. J Neurosci 16:4479-4490.

Euler T, Wässle H (1998) Different contributions of $\mathrm{GABA}_{\mathrm{A}}$ and $\mathrm{GABA}_{\mathrm{C}}$ receptors to rod and cone bipolar cells in a rat retinal slice preparation. J Neurophysiol 79:1384-1395.

Feigenspan A, Wässle H, Bormann J (1993) Pharmacology of GABA receptor $\mathrm{Cl}^{-}$channels in rat retinal bipolar cells. Nature 361:159-162.

Ferroni S, Marchini C, Nobile M, Rapisarda C (1997) Characterization of an inwardly rectifying chloride conductance expressed by cultured rat cortical astrocytes. Glia 21:217-227.

Fletcher EL, Koulen P, Wässle H (1998) GABA $_{A}$ and GABA ${ }_{C}$ receptors on mammalian rod bipolar cells. J Comp Neurol 396:351-365.

Fritsch J, Edelmann A (1996) Modulation of the hyperpolarizationactivated $\mathrm{Cl}^{-}$current in human intestinal T84 epithelial cells by phosphorylation. J Physiol (Lond) 490:115-128.

Greferath U, Grünert U, Wässle H (1990) Rod bipolar cells in the mammalian retina show protein kinase C-like immunoreactivity. J Comp Neurol 301:433-442.

Greferath U, Brandstätter JH, Wässle H, Kirsch J, Kuhse J, Grünert U (1994) Differential expression of glycine receptor subunits in the retina of the rat: a study using immunohistochemistry and in situ hybridization. Vis Neurosci 11:721-729.

Greferath U, Grünert U, Fritschy JM, Stephenson A, Möhler H, Wässle $\mathrm{H}$ (1995) $\mathrm{GABA}_{\mathrm{A}}$ receptor subunits have differential distributions in the rat retina: in situ hybridization and immunohistochemistry. J Comp Neurol 353:553-571.

Grigorenko EV, Yeh HH (1994) Expression profiling of GABA recep- $^{-}$ tor $\beta$-subunits in the rat retina. Vis Neurosci 11:379-387.

Gründer S, Thiemann A, Pusch M, Jentsch TJ (1992) Regions involved in the opening of $\mathrm{ClC}$-2-chloride channel by voltage and cell volume. Nature 360:759-762.

Hamill OP, Marty A, Neher E, Sakmann B, Sigworth FJ (1981) Improved patch-clamp techniques for high resolution current recording from cells and cell-free membrane patches. Pflügers Arch 391:85-100.

Huba R, Hofmann HD (1988) Tetanus toxin binding to and cultured rat retinal glia cells. Glia 1:156-164.

Jarolimek W, Lewen A, Misgeld U (1999) A furosemide-sensitive $\mathrm{K}^{+}$$\mathrm{Cl}^{-}$cotransporter counteracts intracellular $\mathrm{Cl}^{-}$accumulation and depletion in cultured rat midbrain neurons. J Neurosci 19:4695-4704.

Jentsch TJ, Günther W (1997) Chloride channels: an emerging molecular picture. BioEssays 19:117-126.

Jentsch TJ, Günther W, Pusch M, Schwappach B (1995) Properties of voltage-gated chloride channels of the $\mathrm{ClC}$ gene family. J Physiol (Lond) 482:19S-25S.

Jonas P, Bischofberger J, Sandkühler J (1998) Corelease of two fast neurotransmitters at a central synapse. Science 281:419-424.

Jordt SE, Jentsch TJ (1997) Molecular dissection of gating in the ClC-2 chloride channel. EMBO J 16:1582-1592.

Karschin A, Wässle H (1990) Voltage- and transmitter-gated currents in isolated rod bipolar cells of rat retina. J Neurophysiol 63:860-876.

Kawasaki E, Hattori N, Miyamoto E, Yamashita T, Inagaki C (1999) Single-cell RT-PCR demonstrates expression of voltage-dependent chloride channels $(\mathrm{ClC}-1, \mathrm{ClC}-2$ and $\mathrm{ClC}-3)$ in outer hair cells of the rat cochlea. Brain Res 838:166-170.

Kawasaki M, Uchida S, Monkawa T, Miyawaki A, Mikoshiba K, Marumo F, Sasaki S (1994) Cloning and expression of a protein kinase C-regulated chloride channel abundantly expressed in rat brain neuronal cells. Neuron 12:597-604.

Kieferle S, Fong P, Bens M, Vandewalle A, Jentsch TJ (1994) Two highly homologous members of the $\mathrm{ClC}$ chloride channel family in both rat and human kidney. Proc Natl Acad Sci USA 91:6943-6947.

Madison DV, Malenka RC, Nicoll RA (1986) Phorbol esters block a voltage-sensitive chloride current in hippocampal pyramidal cells. Nature 321:695-697.

Marty A, Neher E (1995) Tight-seal whole-cell recording. In: Singlechannel recording (Sakmann B, Neher E, eds), pp. 31-51. New York: Plenum.

McCarren M, Alger BE (1985) Use-dependent depression of IPSPs of rat hippocampal pyramidal cells in vitro. J Neurophysiol 54:557-571.

Misgeld U, Deisz RA, Dodt HU, Lux HD (1986) The role of chloride transport in postsynaptic inhibition of hippocampal neurons. Science 232:1413-1415.

Murray CB, Morales MM, Flotte TR, McGrath-Morrow SA, Guggino WB, Zeitlin PL (1995) ClC-2: a developmentally dependent chloride channel expressed in the fetal lung and downregulated after birth. Am J Respir Cell Mol Biol 12:597-604.

Park K, Arreola J, Begenisich T, Melvin JE (1998) Comparison of voltage-activated $\mathrm{Cl}^{-}$channels in rat parotid acinar cells with ClC-2 in a mammalian expression system. J Membr Biol 163:87-95.

Rivera C, Voipio J, Payne JA, Ruusuvuori E, Lahtinen H, Lamsa K, Pirvola U, Saarma M, Kaila K (1999) The $\mathrm{K}^{+} / \mathrm{Cl}^{-}$co-transporter $\mathrm{KCC} 2$ renders GABA hyperpolarizing during neonatal maturation. Nature 397:251-255.

Rohrhough J, Spitzer NC (1996) Regulation of intracellular $\mathrm{Cl}^{-}$levels by $\mathrm{Na}^{+}$dependent $\mathrm{Cl}^{-}$cotransport distinguishes depolarizing from hyperpolarizing GABA receptor-mediated responses in spinal neurons. J Neurosci 16:82-91.

Sakamoto H, Kawasaki M, Uchida S, Sasaki S, Marumo F (1996) Identification of a new outwardly rectifying $\mathrm{Cl}^{-}$channel that belongs to a subfamily of the $\mathrm{ClC} \mathrm{Cl}^{-}$channels. J Biol Chem 271:10210-10216.

Sanger F (1977) Determination of nucleotide sequences in DNA. Science 214:1205-1210.

Schwiebert EM, Cid-Soto LP, Stafford D, Carter M, Blaisdell CJ, Zeitlin PL, Guggino WB, Cutting GR (1998) Analysis of ClC-2 channels as an alternative pathway for chloride conduction in cystic fibrosis airway cells. Proc Natl Acad Sci USA 95:3879-3884.

Segal M, Barker JL (1984) Rat hippocampal neurons in culture: properties of GABA-activated $\mathrm{Cl}^{-}$conductance. J Neurophysiol 51:500-515.

Smith RL, Clayton GH, Wilcox CL, Escuerdo KW, Staley KJ (1995) Differential expression of an inwardly rectifying chloride conductance in rat brain neurons: a potential mechanism for cell-specific modulation of post-synaptic inhibition. J Neurosci 15:4057-4067.

Staley K (1994) The role of an inwardly rectifying chloride conductance in postsynaptic inhibition. J Neurophysiol 72:273-284.

Staley K, Smith R, Schaack J, Wilcox CL, Jentsch TJ (1996) Alteration of $\mathrm{GABA}_{\mathrm{A}}$ receptor function following gene transfer of the ClC-2 chloride channel. Neuron 17:543-551.

Staley KJ, Soldo BL, Proctor WR (1995) Ionic mechanisms of neuronal

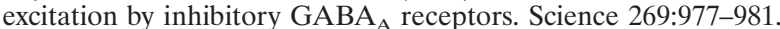

Steinmeyer K, Ortland C, Jentsch TJ (1991) Primary structure and functional expression of a developmentally regulated skeletal muscle chloride channel. Nature 354:301-304.

Thiemann A, Gründer S, Pusch M, Jentsch TJ (1992) A chloride channel widely expressed in epithelial and non-epithelial cells. Nature 356:57-60.

Thompsom SM, Gähwiler BH (1989a) Activity-dependent disinhibition. I. Repetitive stimulation reduces IPSP driving force and conductance in hippocampus in vitro. J Neurophysiol 61:501-511.

Thompsom SM, Gähwiler BH (1989b) Activity-dependent disinhibition. II. Effects of extracellular potassium, furosemide and membrane potential on $\mathrm{ECl}^{-}$in hippocampal CA3 neurons. J Neurophysiol 61:512-523. Uchida S, Sasaki S, Furukawa T, Hiraoka M, Imai T, Hirata Y, Marumo F (1993) Molecular cloning of a chloride channel that is regulated by dehydration and expressed predominantly in kidney medulla. J Biol Chem 268:3821-3824.

Williams JR, Sharp JW, Kumari VG, Wilson M, Payne JA (1999) The neuron-specific K-Cl cotransporter, KCC2. J Biol Chem 274:1265612664. 